\title{
小特集 運転者の知覚・認知能力の診断と補償
}

\section{1. 運転中に何を見て，何を認知しているのか}

～道路，交通，運転特性，そして高齢ドライバ〜

赤松 幹之门

キーワードロ自動車運転, 視鸴, 運転支援, 高齢者, 道路, 交通

\section{1.まえがき}

自動車運転においては，時々刻々状況が変化しており， さらに先行車に追従しているのか交差点を右折しょうとし ているかなど，運転タスクによっても知覚・認知対象は異 なる。したがって，どのような運転場面や運転状況におけ る知覚・認知能力を診断したいかを明確にして, それに合 った診断・評価法を適用しなければならない。

自動車運転は, 他車両や歩行者など他の交通参加者がい る道路上を，道路からの逸脱や他者との衝突を避けながら 目的地に至るまで，自分の車両を制御して走行させる。し たがって, 自動車運転中の具体的な知覚・認知の対象とし ては，道路環境に係わるもの，他車両等によって作られる 交通状況に係わるもの, 自車両の挙動に係わるもの, に大 別することができる．また，ドライバ自身の運転能力や自 分の状態などの認知もある。さらに，これらを統合して， リスクの認知など自らがおかれている状況認知が行われて いる.

以下では，まず2章で知覚・認知能力の評価方法につい て概説し，3章以降では, 道路環境, 交通状況など, 個別 の知覚・認知について解説し，それぞれにおいて高齢ドラ イバ特性を中心に幾つかの評価事例およびそのポイントを 紹介する．7章では，知覚・認知能力を補償するための方 法や技術について簡単に紹介する。 なお, 本稿では, 厳密 な線を引くことは難しいことから，「知覚」と「認知」を明 確に定義せずに使用することをお許しいただきたい.

\section{2. 自動車運転に関わる知覚・認知能力の評 価方法}

運転における知覚・認知能力を評価する方法は, 質問紙 等によって自覚されている知覚・認知能力を評価する方法 と, 何らかのタスクを課してその成績で知覚・認知能力を 評価する方法に大別できる。

\footnotetext{
†独立行政法人産業技術総合研究所

"Perception/Cognition of Road, Traffic Condition and Driving Characteristics for Car Driving" by Motoyuki Akamatsu (Institute for Human Science and Biomedical Engineering, National Institute of Advanced Industrial Science and Technology (AIST), Tokyo)
}

\section{1 質問紙による評価}

質問紙法は，運転場面における知覚・認知能力に関する 質問文に対して，自分にどの程度当てはまるか答えてもら うものである。このとき，運転場面の設定をいかに適切に 文章表現するかがポイントとなる。一般的な運転場面の質 問にすると回答者は答えにくいし，質問者としては運転場 面を限定したつもりでも，質問者の想定していた運転場面 と回答者が想定した運転場面が異なることが起きうる。予 備的調査で，そういった問題をなくすような工夫が必要で ある。

\section{2 タスクを用いた評価}

(1) 知覚検査, 心理検査による評価

タスクを課してその成績によって評価する方法では，実 際の運転タスクをいかに適切に抽象化できるかが重要にな る. 知覚・認知機能を要素的に分解することができれば, 運転場面を想定しない抽象的なタスクによって能力を評価 できる．視力検査や視野検査は単純な刺激による知覚検査 である．また，認知的能力を抽象化した方法で評価する方 法としては，心理検査を用いて評価することができる加齢 による認知機能検査などがある1) (図1)。これらは，運転夕 スクに使われる機能を，運転場面を想定させずに評価する ものといえる。

(2) 反応時間タスク，トラッキングタスクによる評価

運転タスクを模擬しながらも抽象化されたタスクによる 評価としては，反応時間タスクやトラッキングタスクがあ

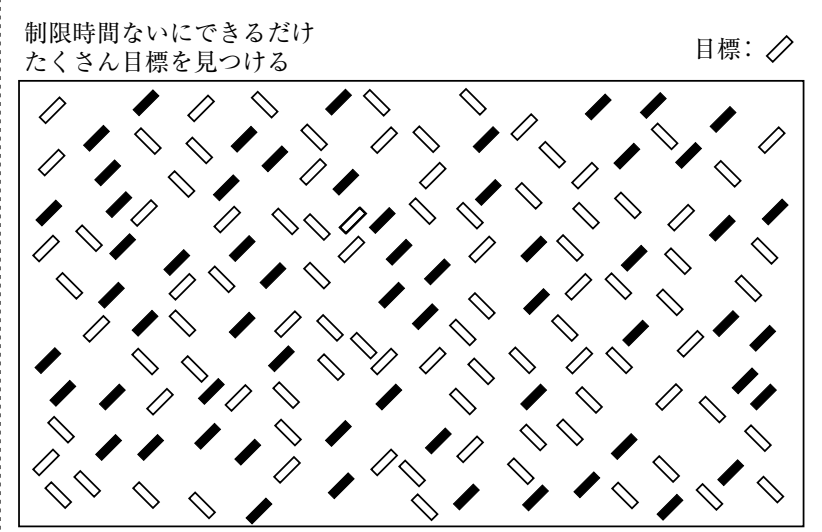

図 1 注意機能検査

映像情報メディア学会誌 Vol. 61，No. 12, pp. 1682〜1688（2007） 


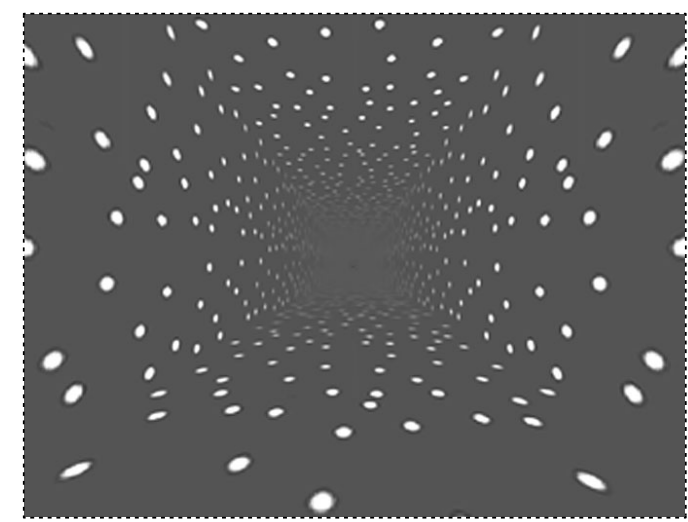

図2 ランダムドットパタンによるオプティックフロー

る. 反応時間タスクは, 赤信号や先行車のブレーキランプ の点灯に対する知覚・反応を模擬したものであり, トラッ キングタスクは曲がりくねった道路に添ってハンドル操作 をするタスクを抽象化したものである.

(3) オプティックフローや線画による抽象化画像による 評価

自動車運転においては視覚情報が主な手掛かりであると 考えられていることから, 視覚的な運転場面を抽象化する ことができる. 自動車運転において, 道路構造の知覚には 道路風景の像の流れであるオプティックフローが手掛かり となる. したがって, ランダムドットパタンを用いて抽象 化されたオプティックフローにより知覚・認知能力を評価 することができる (図2). また，オプティックフローだけ でなく, 道路の白線なども手掛かりであることから, 道路 の線画を用いて知覚・認知能力を評価することもできる.

(4) 運転シーン画像の呈示による評価

抽象化した視覚刺激ではなく, 実際の運転場面を呈示し て知覚・認知能力を評価することもある. 運転シーンをカ メラで撮影して, その静止画像を呈示して何に気付くか調 ベたり, 運転シーンの連続ビデオ画像等を再生呈示する方 法である.これは運転場面におけるリスク知覚能力の評価 などに使われるが，実際に自分で運転していないので時間 的に余裕があることが実際とは異なる．また，時間的制約 を課すために短時間のビデオ画像の呈示によって行うこと もある。

（5）ドライビングシミュレータ, 試験走路での走行によ る評価

実際の道路上での運転に近い状態を再現して知覚・認知 能力を評価する方法として，ドライビングシミュレータを 用いた方法と試験走路での走行を用いた方法がある. ドラ イビングシミュレータは事故による危険の心配がなく，ま たほぼ同じ運転状況を再現して繰り返して呈示できるメリ ットがある ${ }^{2)}$. しかし, シミュレータは完全に運転状況を 再現できるものではないことから，目的に応じて何をより 正確に再現するかを考えて実施しなければならない.また，
実際の走行ではないことから，ドライバの感じる危険感や リスク感は実際よりも低くなることは避けられない。

試験走路での走行は，より実際の運転に近いものであり， 実車両を使うので車両挙動も含めた評価ではシミュレータ よりも実際に近い3). 周回試験場は都市間高速道路を模擬 したものとみなすことはできるが，仮設物だけでは一般道 路や市街地を模擬することは難しい. また，試験走路で他 車両との関係の知覚・認知を評価する場合には, 自車両と 他車両との位置関係を統制するため工夫が必要である．実 車両を用いても，予期しない状況変化がおきないために， 危険感やリスク感は低くなりがちである.

(6) 実際の路上での運転による評価

実路上での自動車運転からドライバの知覚・認知能力の 評価をするのは，一見理想的であるように思われるが，実 際には実路上での運転状況は極めて多様であり，二度と同 じ状況が再現されることはない。したがって, 実路で得ら れた結果が果たして他の場面でも同じになるかはわらな い.そのために, 統計的な議論ができる程度に充分なデー 夕を得なければならない。

以上のように，ドライバの知覚・認知能力の評価をする ためには，さまざまなレベルで運転を抽象化した方法があ る. 評価をしたい知覚・認知能力が明確に要素分解されて いれば，その本質的な点を抽象化した刺激や条件で評価す ることができる. その一方で, 評価したい知覚・認知能力 が要素分解できない総合的なものであったり，運転場面に 依存したものであれば，実際の運転に近いもので評価しな ければならない。

以下では, 運転中の知覚・認知の対象について概説して, それぞれにおいて適用できる評価方法について述べる。

\section{3. 道路環境の知覚・認知}

(1) 横断線形 (カーブ)

カーブの曲りのことを横断線形と呼ぶ.カーブの部分は 円弧になっており，曲率は一定であるが，直線部とカーブ 部は緩和曲線区間と呼ばれる曲率が漸増する部分でつなげ られている。したがって, 横断線形に関わる知覚としては, カーブ部分の曲率だけでなく, 緩和曲線区間における線形 の変化の大きさも対象となる。実際, 緩和曲線区間を長く 取りすぎると，カーブ進入時に全体の曲率がわかりにくい ことがおきる。これらの知覚には外側線や中央線の曲り具 合が手掛かりであるが，その他，ガードレールの見え方， 道路脇の植栽などの変化も手掛かりである.

試験走路内のカーブを高齢者に走行してもらい，非高齢 者と比較した研究によると ${ }^{4)}$, 高齢者はカーブ進入時にハ ンドルの切り遅れがあり, また操作が滑らかではない.こ れには, カーブの曲率の知覚の問題だけでなく, カーブに 対する車両挙動の知覚の問題, 操作の滑らかさの問題など, 種々の要因が関係しているものと考えられる. 
(2) 縦断線形 (上り下り勾配)

上り下りの勾配のことを縦断線形と呼ぶ. 元の地形に依 存して道路の勾配を決めるために, 勾配が変化するところ も多い. 大きく勾配が変化するところが縦断線形での大き な特徴点であり, 上り勾配が下り勾配に変化するところを クレスト，下り勾配が上り勾配に変化するところをサグと 呼ぶ.

縦断線形の知覚には, 外側線や中央線からの視覚的な手 掛かりが主な役割を果たしていると考えられる。そのため に，長い勾配が続くところでは視覚的手掛かりの変化がな くなるために, 勾配が知覚しにくくなる. 実際の運転中に は，勾配によるエンジンへの負荷の増加または減少からも 手掛かりとなる。

縦断勾配の変化，とくにサグ付近では，下り勾配のあと に平坦部になっているか, 上り勾配に反転しているかが知 覚しにくい. そのために, 上り勾配で速度低下がおきやす く，それが原因で渋滞がおきることがある.また，そのた めに追突事故が起きやすい場所である。これは，外側線， 中央線の視覚的な手掛かりだけでは相対的な変化しか知覚 できないためである.

(3) 交通信号機

高歯者ドライバの事故統計をみると，事故全体に対する 信号無視による事故の比率が高い ${ }^{4)}$. 赤信号に気付かない ことが原因であるとすると, 加齢によって網膜周辺部の赤 緑系の色コントラスト感度が低下していること, また加齢 によってまぶたの垂れが起きており，視野の上方の物体が 見えていないこと,さらに緑内障などによる視野欠損など が原因として考えられる.

(4) その他

道路に付帯して設置されているものとしてトンネルがあ るが, トンネルの内外の明るさの差が大きいことから, 視 覚における順応機能が問題となる. 高齢者になると順応時 間が長くなることが知られている，道路には道路標識が設
置されているが, 標識の文字も運転中の知覚・認知の対象 である．高齢者になると，非高齢者に比べて接近にならな いと知覚できないが, 文字の画数が多くなると, この非高 齢者との差が大きくなる ${ }^{4)}$ 。この他, 道路の路面の湿潤状 態なども知覚・認知の対象であり, 積雪時には重要な問題 になる。

\section{4. 交通状況の知覚・認知}

\section{1 物体の検知}

交通状況を認知するためには，まず道路およびその周辺 に存在する交通参加者が存在することを知覚しなければな らない. 網膜上に結像した像が視覚的信号となって知覚に 至るかどうかは，網膜の時空間特性による，正弦波で空間 的また時間的に変調した刺激を視野のさまざまな位置に呈 示して時空間特性を調べると, 視野の中心部は空間周波数 特性も時間周波数特性も良いが，例えば， $2 \mathrm{~Hz}$ 程度の時間周 波数の場合には，周辺部になってもあまり感度は低下しな いなど (図3), 周波数帯域によって特性が異なる ${ }^{5)}$. 色コン トラストについても, 黄青コントラストの高時間周波数帯 域では，視野の位置による差は少ないが，赤緑コントラス トの低時間周波数帯域においては中心部の感度が高い.

対象物を注視していれば，対象物の網膜上の像の位置は 中心にあるが，進行方向の道路上に眼球を向けている場合 には，他の交通参加者は必ずしも視野の中心部にはない. したがって，視野のうちのどの位置で，どのような背景色 の元で, 何色のどれだけの大きさの車両や歩行者がどのよ うに動いているかによって知覚できるかが異なる.

\section{2 他車両の動きの知覚}

(1) 先行車両の知覚

自動車運転における他車両の動きの知覚で，もっとも頻 繁に行われているのが, 先行車との距離の知覚であろう. 一般に, 車間距離は走行速度によって変化し, 速度が速く なると車間距離を長くとる。したがって，車間距離を速度
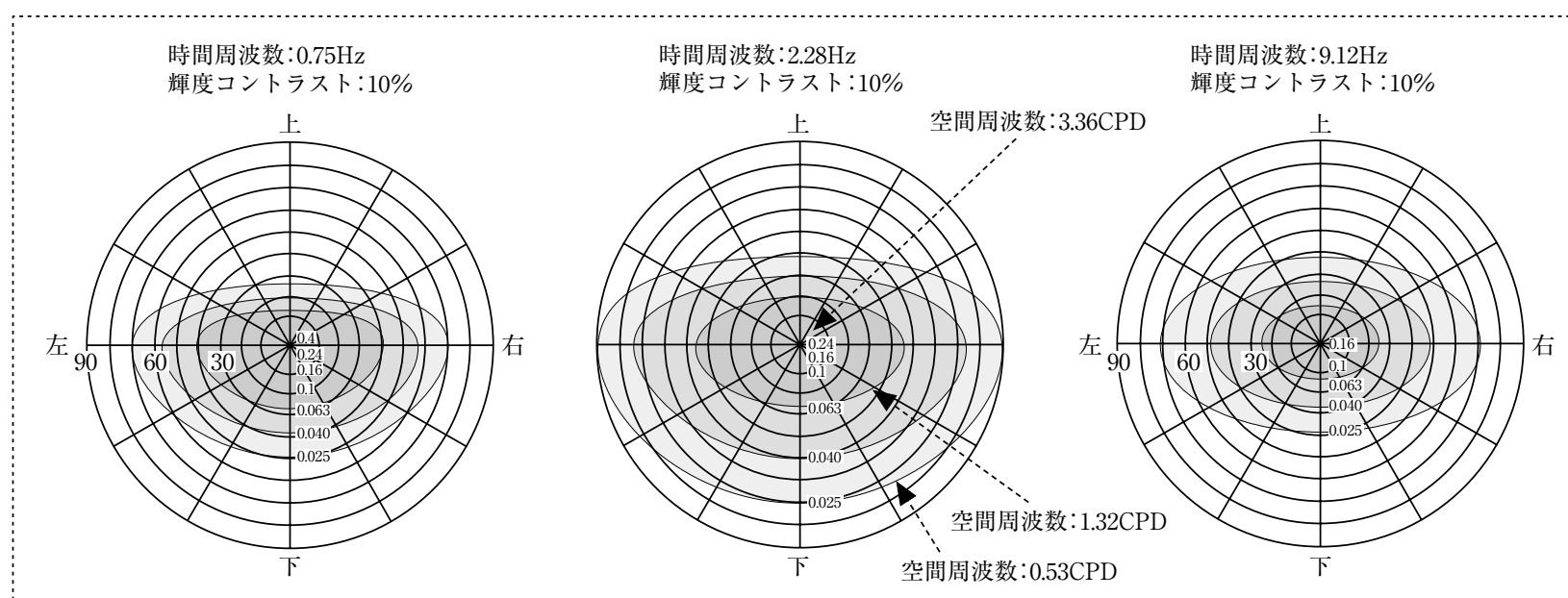

図3 視野の時空間周波数特性 

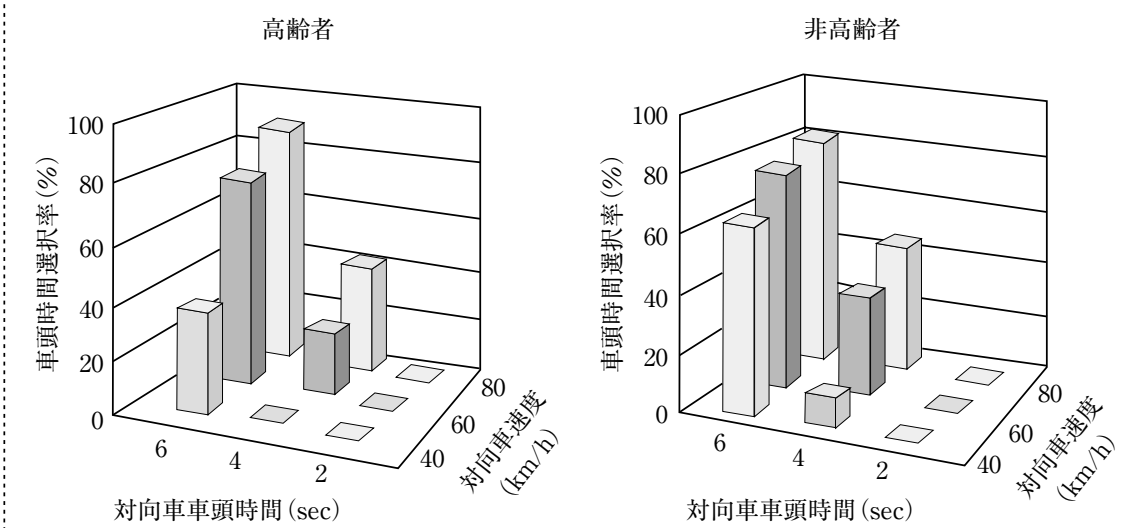

図4交差点における右折開始可能の判断

で除した車間時間を指標として用いることが多い.シミュ レータを用いた実験であるが，先行車への衝突に対する危 険感は車間時間の逆数にほぼ比例することが認められ6), ドライバは衝突に対する危険感の認知に基づいて車間時間 を選定していると考えられる.

先行車に追従しているとき，先行車が減速をすると，後 続車のドライバはそれを知覚して減速を開始する. 先行車 の減速の知覚の手掛かりとしては, ブレーキランプの点灯 があるが，エンジンブレーキによる減速や上り勾配のため の減速の場合にはブレーキランプは手掛かりとしては使え ない. 先行車に対する接近状態は, 車間距離を相対速度 (速度差)で除したTTC (Time to Collision)を指標とするこ とが多い.しかし, 実験的に調べると, 先行車両の見た目 の大きさの増大 (視角の変化速度) が減速夕イミングと相関 が高い. したがって, 視角変化速度が先行車減速の知覚の 手掛かりになっていると考えられるが，この指標はTTCの 逆数と比例関係にある ${ }^{7)}$.

(2) 接近車両の知覚

交差点で右折する場合には, 対向直進車両が交差点に到 達するために充分な距離があることを認知して右折を開始 する.この右折車と直進車との事故は交差点での事故の典 型であり，この事故が高齢者に多いことが事故統計から示 されている. 試験走路を用いて, 接近対向車に対する右折 の可否の判断に関する実験を行った結果をみると, 非高齢 者に比べて高齢者は右折可能と判断したときの車頭時間間 隔 (2台の車両の先端部間の距離を車速で除したもの) は長 い. しかしながら, 種々の速度で実験を行うと, 非高齢者 では速度に関わらずほぼ同じような時間間隔のときに右折 可能と判断しているのに対し, 高歯者は速度が速いと同じ 車頭時間間隔でも右折可能と判断する (図4). 同じ車頭時 間間隔であっても速度が速くなると遠くに見えており，遠 くに見えれば充分な余裕があると高齢者は判断しがちであ ることが示唆される4). いいかえれば, 非高歯者は接近車 両の到達時間を予測・認知して判断しているが, 高齢者は
距離の知覚を手掛かりとして，接近速度を考慮に入れずに 判断をしている.

T字路での非優先道路から優先道路への合流時における, 側方からの接近車両の知覚においても，同様に高齢者は距 離の知覚を手掛かりとして，接近速度を考慮に入れずに判 断をしている ${ }^{4)}$. 高齢者事故の特徴である出合い頭衝突事 故や優先通行妨害による事故は，停まり方が不充分である という面と優先道路側の接近車両の誤認という面があると 考えられる。

(3) 十字路の側方接近車両の知覚

信号のない交差点において, 見通しの良い交差点であっ ても出会い頭の事故が起きている．物理的には互いが見え ているはずなのに相手車両に気付かない原因として，上述 した視野における時空間特性が挙げられる，出会い頭で衝 突する条件で互いに交差点に等速で接近している場合, 相 手車両が存在する位置と自車両の進行方向とのなす角度は 一定となる. したがって, 進行方向に眼球を向けていると すると, 相手車両の像は網膜上の同じ位置に結像すること になる，すなわち，相手車両が走行しているにも関わらず 視野上では動きがなく, 視野周辺部で感度の低い低時間周 波数の刺激になっている. そのために, 相手車両が知覚し にくいものと考えられる.

\section{5. 自車両の走行状態の知覚・認知}

自車両の走行状態としては, 車両の速度, 加速度, 進行 方法および曲り具合などを知覚する必要がある。速度は速 度計に頼ることも多いが, 道路風景のオプティックフロー から知覚することができる. ランダムドットを用いて作ら れたオプティックフローを用いた実験によると，オプティ ックフローによる速度知覚はフローの速度の総和と関係す る8). したがって, 周辺視野が制限されている場合には速 度感が低下する。

車両の加速度については, 前庭系からの加速度の知覚が 主な手掛かりと考えられているが，それ以外にも視覚的に 
オプティックフローの速度変化も手掛かりとして用いるこ とができる．実際の運転中は，これ以外にもエンジン音や 排気音の変化などの聴覚的な手掛かりも加速感に影響する. 停止線での停車のための減速度の知覚も, 同様に前庭系か らの信号とオプティックフローの変化が主な手掛かりであ ると考えられるが, 減速度と位置との関係は2次関数になる ことから，停止位置を認知 (予測) することは簡単ではない と考えられ, 運転の経験によって獲得するものと思われる.

道路上を直進する場合には, 自車両の進行方向と道路の 方向が一致していることを認知できなければならない. 車 両の進行方向はオプティックフローの沸き出しロとなるこ とから, オプティックフローの沸き出し口と道路の消失点 が一致していれば，車両と道路の方向は一致していること になる．実際の運転ではオプティックフローだけでなく, 視野上での道路上の外側線や中央線の位置の変化なども手 掛かりとしていると考えられる. 道路のカーブ部分につい ても同様に，オプティックフローから車両の曲り具合が知 覚できるが, 視野上での道路上の外側線や中央線の位置の 変化なども手掛かりとしていると考えられる.

一方, 車両自体の知覚としては, 車両幅や長さ, 高さな どの車両のディメンションの知覚がある。車体のボンネッ トの先端位置などは視差によって位置が知覚できるはずで あるが，対象の大きさやパースペクティブなども手掛かり となる. しかし, 車体のデザイン上でボンネットの先端部 分が見えないと, その位置から先の部分の長さは自分で推 定しなければならないこと, また車両の移動に伴って自車 両と障害物の位置が変化するために予測も必要であり, 多 くの要因がかかわっている.

\section{6. リスクの知覚・認知}

これまでに述べてきた他車両の接近の知覚などは，事故 などに至る可能性につながる, いわばハザード（顕在化し た危険）の認知に関わる問題である。これに基づいて減速 などの回避行動を取ったり，進路を修正したり，発進を断 念したりする。一方，リスクすなわち顕在化していない危 険の認知は，危険が潜んでいそうなところに注意を向けた り, いつでも回避行動がとれるように準備したりするため の認知である.

運転者教育においては, 運転場面の画像を呈示して, ど こに注意を払うかを答えさせることで，どこにリスクがあ ると感じているか調べることが行われている. また, 状況 認知 (Situation Awareness) という概念があり，これは自 分の周りに何がどのように配置しているか, そしてそれが どういう意味を持っているかを認知することである (図5). リスク認知は状況認知に基づいて行われていると考えられ ることから，状況認知を調べることも行われている．その 方法として, 運転シーンの動画を見せて, ある時点で画像 を消し，そのあとでシーンに他車両がどのように配置され ていたかを答えさせる.これによって，自車の周辺のどの 範囲までの状況が認知できていたかを評価する.

\section{7. ドライバの情報処理資源の評価}

考え事, 会話, 音楽鑑賞など運転に関係のない作業は, 運転に対する知覚・認知能力を低下させる. 人の情報処理 容量には限界があることから，運転以外のことに情報処理 資源を投入してしまうと，運転に投入する情報処理資源が

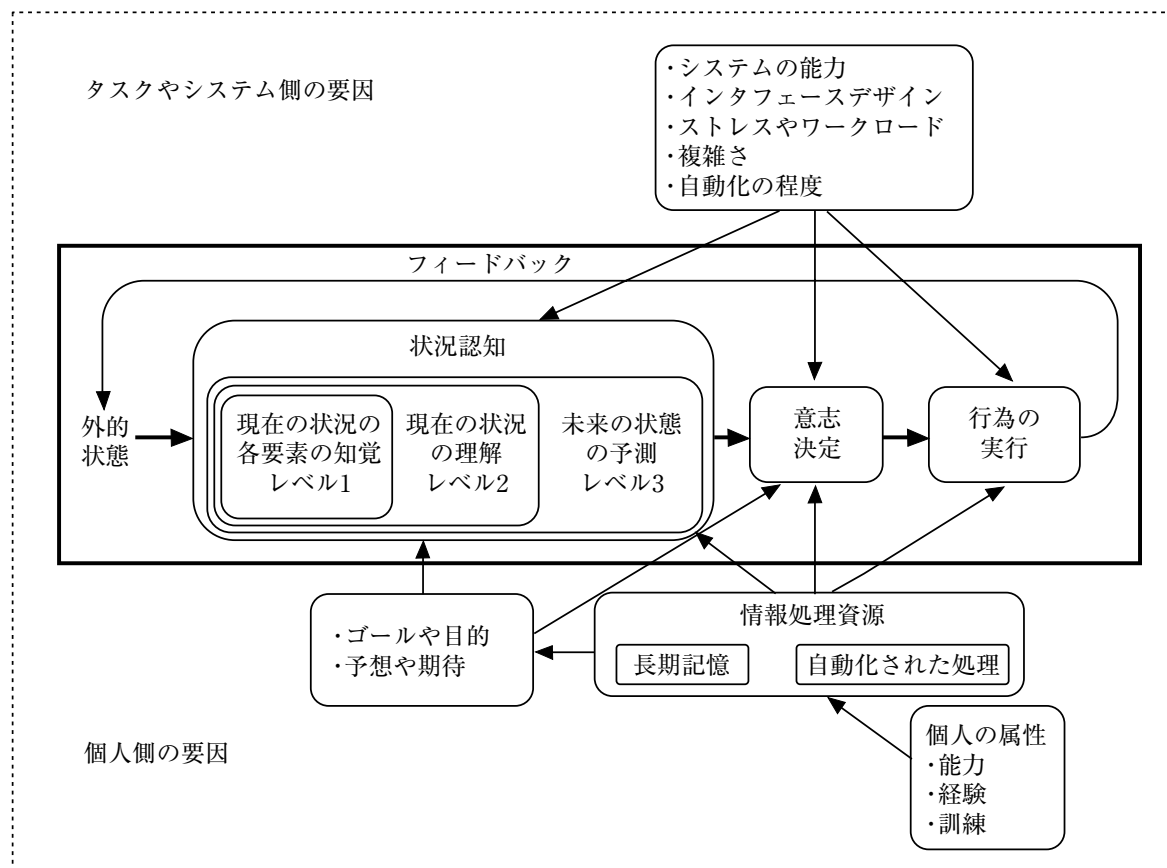

図5Ｅndseyの状況認知 (SA) モデル (一部改変) 
減少すると考えられている. 情報処理容量は年齢や運転ス キルなどの個人差によって異なるとともに，同一ドライバ であっても覚醒水準や疲労などによって減少すると考えら れている，このために，眠気や疲労の計測によって，ドラ イバの知覚・認知能力のレベル低下を評価することも考え られている。

情報処理容量が大きくても, 運転に関係のない脇見や作 業は運転への投入リソースを減らすものであり，このよう な運転を阻害することをドライバディストラクションと呼 び，その影響度を計測する研究が増えてきている．走行し ている道路シーンから視線が外れている場合を脇見と呼ぶ が, 直接的には眼球運動計測によって, 車室内を見ている など脇見状態であるかを計測することができる．これを強 制的に行うことができるのが液晶シャッ夕眼鏡であり，こ れを用いて運転タスクにおける視覚的なディマンドの大き さを評価することができる.

必ずしも脇見の定義は明確ではないこと, また前方に目 が向いていても運転に必要な情報を獲得しているかはわか らないことから, 運転タスクに加えて副次タスクを課すこ とで，間接的に運転に投入している資源を計測することも 行われている．視野の周辺部に設置したランプや運転シー ン内の先行車両のブレーキランプの点灯など単純な刺激に 対してボタン押し等で反応する反応時間タスクを副次タス クとし, 主タスクとして運転操作等を行わせる. ランダム なタイミングでランプを点灯させて，それに対する反応時 間やエラー率を計測する，反応時間が長くなったり，ラン プの見落としエラーが多い場合には, 主タスクの負荷が高 かったと評価する．主タスクは運転操作だけの場合もある が, 車載機器の操作なども含めて行うこともできる.

車載機器の操作など運転以外の夕スクの認知的負荷を調 ベるために，パソコン上での簡易な模擬運転を用いること も提案されている.ここでは, 車載機器操作などの副次夕 スクと平行して連続した車線変更を行なわせて, 車線変更 の成績から副次タスクの認知的な負荷の大きさを評価しょ うというものである.

\section{8. 運転能力の自己認知}

個人個人のドライバ特性を調べるためには，心理検査や 質問紙を用いることが多い. 例えば，どういった運転場面 で負担を強く感じるかを調べる運転負担感受性のチェック シートを用いると, 負担感の高い場面における知覚・認知 の能力が，そのドライバは低いと評価できる ${ }^{9)}$. 高齢ドラ イバの運転機能の変化についても質問紙によって調べるこ とができる，運転中のさまざまな場面における知覚・認知 機能について, 加齢に伴って以前よりも低下しているかを 答えてもらう。例えば，「以前に比べ赤信号が見えにくく なった」,「以前に比べ歩行者や自転車が煩わしいと感じる ようになった」といった記述に対して, 自分がどの程度当
てはまるかを答えてもらう。この質問文は，ほぼ知覚，理 解・予測, 判断・意図形成, 実行という認知プロセスに対 応しており，ドライバごとにどの認知プロセスの機能低下 が顕著であるかを評価することができる10).

この他，上述したようなそれぞれの知覚・認知能力の評 価方法で得られた結果を, ドライバ本人に伝えることで, 自己の運転能力を知ることができる.

\section{9. 知覚・認知能力の補償}

上記のように，自動車運転にはさまざまな知覚・認知能 力が必要であるが，これらは自動車運転を行うことで獲得 されるものが多い. しかし，加齢によってこれらの機能が 低下してくる，これを補償するための方策として，教育訓 練による機能低下の抑止や運転支援装置による補助が期待 されている.

最近では高齢ドライバ教育が盛んになってきており, 高 齢者事故の特徵などを教えることで, 高歯令ドライバ自身で 問題になりがちな場面で意識して運転をすることが期待さ れる．例えば，高齢者は赤信号を見落としがちであると教 えることで，信号を常に意識して確認しながら運転するよ うになると期待される.

高齢者であるという意識から，自分で運転の仕方を変え るようにしている人も多い。例えば，夜間は運転しない， 知らない道は走らない, 長時間の運転は避ける, といった ことが行われており，これを対処行動と呼ぶ.この対処行 動は自分の運転機能の低下と見合ったものでなければなら ないことから, 質問紙調査によって機能変化している認知 機能に対応した対処行動をしているかを評価することも試 みられている11). しかしながら, 高齢者の場合には, 自覚 している自分の運転能力と実際の運転能力の間にはギャッ プがあり，質問紙を用いることの限界がある。この問題の 解決には, 同乗調査などで実際の運転を評価する必要があ る. 高齢ドライバの自己評価は同乗者による評価に比べて 高くなるが，具体的に問題点を指摘すると自己評価は下が るとともに, 一時停止で充分減速しないなどの問題点が解 消される.ただし，その効果の持続期間については明らか ではない.

教育訓練によってドライバ自身に運転の仕方を変えても らうことには限界がある。そこで，知覚・認知機能低下に 対して，それらを補償するような運転支援装置を適用する ことが考えられる．従来からあるバックソナーまた最近広 まったリアビューモニタは, 車両感覚にかかわる知覚機能 を支援するものである。道路環境の知覚・認知支援として は, 狭路走行支援システムの提案もなされている ${ }^{12)}$. また, 都市内高速でのカーブ進入速度注意喚起システムも検討さ れている. 交通状況の知覚・認知能力を補助するものとし ては，車間距離に関しては，車間距離センサの導入も考え られる. 車両の接近に関しては, 交差点右折時の対向車の 
接近を伝える警報システムの提案がなされている. その他， 前方障害物や側方障害物衝突警報システムも交通状況の知 覚・認知の支援となる。しかしながら, 支援装置による情 報呈示は, 道路交通状況に対する知覚・認知を妨げること がないようにしなければならない。また，過度の警報や注 意喚起によって煩わしさを与えると, システムを使っても らえなくなることにも注意しなければならない.

知覚・認知能力全体が低下した状態をセンシングして, その低下を補償するために, 運転中の覚醒度や瘦労度を検 知する技術の研究が長く行われている. 画像処理によって 閉眼を検知したり，心拍や体表温度などの生体信号に基づ くもの, 体動から検知するものなどが提案されてきている. しかしながら，センシング結果をどのように使って補償す るのかが大きな課題である．ドライバ自身に覚醒度の低下 を知らせたり，疲労度を知らせても，ただちに休憩をとる といった対応は期待できない。覚醒度を高めるために匂い 刺激を与えたり, 警報音を鳴らすなどの提案があるが, 決 め手はない. また，こういったドライバ状態のセンシング の結果を，運転支援装置での情報呈示の制御に使うことも でき，知覚・認知機能が低下している場合には，警報の夕 イミングを早めることで補償することができる.

\section{0. むすび}

自動車運転において行われている知覚認知について概説 をしたが, 自動車運転の知覚・認知能力を評価するために はさまざまな側面から行うことができる.したがって，何 を評価したいのかよく考えて計測法を選ばなければならな い. 運転中の道路交通状況に対する具体的な知覚・認知と しては, 道路上の個別の物体の知覚の能力から, リスクな ど総合的な状況認知の能力まで, 幾つかのレベルがある. また, 個別の対象に対する知覚・認知の能力ではなく, 知 覚・認知に投入されている情報処理リソースなどの全体的 な知覚・認知能力を評価することもできるが，これもある 瞬間の知覚・認知能力を評価したいのか, ドライバの持っ ている属性としての知覚・認知能力を評価したいかによっ て, 評価方法が違ってくる. さらに, タスクを課す場合に は，どれだけ抽象化したタスクを行なわせるのが適切であ
るのかをよく考えて, 評価方法を選定しなければならない.

(2007年8月31日受付)

\section{〔文 献〕}

1）熊田, 北島, 小木, 赤松, 山崎：“ユーザビリテイ評価のための高齢 者の注意・遂行機能評価テストの作成”, 第3回日本認知心理学会予稿 集, p.24 (2005)

2）赤松, 大貫：“ドライビングシミュレータにおけるリアルワールド再 現技術の最新動向”，自動車技術，61，7, pp,78-84（2007）

3）赤松：“計測用車両を用いた実路運転でのドライバ評価”，自動車技 術, 58, 12 (2004)

4）赤松, 池原：“高齢ドライバと道路交通環境”, 高齢者運転適正ハン ドブック，自動車技術会，pp.17-32（2005）

5）舟川：“ドライバの視野特性と視覚行動”, 自動車技術, 58, 12, pp.16-21 (2004)

6) T. Kondoh, T. Yamamura, S. Kitazaki, N. Kuge and E.R. Boer: "Identification of Visual Cues and Quantification of Drivers' Perception of Proximity Risk to the Lead Vehicle in Car-Following Situations", Proceedings of DSC Asia/Pacific (CD-ROM) (2006)

7) R.J. Kiefer, D.J. LeBlanc and C.A. Flannagan: "Developing an Inverse Time-to-Collision Crash Alert Timing Approach Based on Driver's Last-Second Braking and Steering Judgements", Accident Analysis and Prevention, 37, pp.295-303 (2005)

8) K. Segawa, H. Ujike, K. Okajima, and S. Saida: "Effects of Visual Field on Perceived Speed of Self-Motion from Optic Flow", Perception, 32 suppl., p.71 (2003)

9）石橋, 大桑, 赤松：“運転スタイル・運転負担感受性の個人特性指標 と運転行動”，自動車技術，58，12, pp.34-39（2004）

10) M. Akamatsu, K. Hayama, A. Iwasaki, J. Takahashi and H. Daigo: "Cognitive and Physical Factors of Functional Change in Car Driving of Elderly People and Their Mobility Life -Questionnaire Study in Different Regions in Japan-" , IATSS RESEARCH, 30, 1, 38-51 (2006)

11) 佐藤, 赤松, 岩崎, 今泉, 醍醐：“認知的・身体的機能の変化に適応 した高齢ドライバの対処行動の分析”，自動車技術会論文集，38，4, pp.209-214 (2007)

12)佐藤, 川嶋, 大門, 池田, 木下：“狭路走行支援システム使用時にお ける高齢ドライバ特性に関する研究”, 人間工学, 40, 1, pp.1-11 (2004)

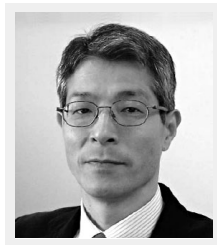

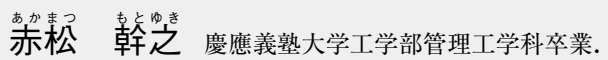
慶應義塾大学大学院工学研究科修了. 通産省工業技術 院 製品科学研究所入所. その後, 生命工学工業技術研 究所 神経情報研究室室長, フランスCNRS認知神経科 学研究所訪問研究員, 産業技術総合研究所人間福祉医 工学研究部門行動モデリンググループ室長などを経て, 2005月より, 研究部門長. 人間工学一般, 生体計測, ITSヒューマンイン タフェース, 運転行動計測・モデル化などの研究に従事. 工学博士. 